\title{
Democratic statecraft in the 'unsettled' global south
}

\begin{tabular}{|c|c|c|}
\hline $\begin{array}{l}\text { The global economy has stalled } \\
\text { in the wake of the Coronavirus } \\
\text { pandemic and the future is } \\
\text { uncertain, particularly for } \\
\text { developing countries. The } \\
\text { move from a state of unsettled } \\
\text { globalisation to global crisis is } \\
\text { the latest in a series of critical } \\
\text { junctures for the international } \\
\text { political economy. In a concept } \\
\text { paper for the International } \\
\text { Political Science Association } \\
\text { (IPSA), Lourdes Sola from the } \\
\text { University of São Paulo in Brazil } \\
\text { and Laurence Whitehead from } \\
\text { the University of Oxford in the } \\
\text { United Kingdom challenge } \\
\text { political scientists to rethink the } \\
\text { democratic state-crafting options } \\
\text { for emerging market economies. }\end{array}$ & $\begin{array}{l}\text { his article provides an overall } \\
\text { interpretive framework for assessing } \\
\text { the dynamics and trajectory of } \\
\text { the major democratic regimes of the } \\
\text { global South since the peak of the } \\
\text { "liberal internationalist" ascendancy that } \\
\text { followed the end of the Cold War and the } \\
\text { dissemination of so called "Washington } \\
\text { Consensus" economic reforms in the } \\
\text { 1990s. It does so from a comparative } \\
\text { perspective, and by emphasising the } \\
\text { standpoints of policy-makers at the } \\
\text { "periphery" of the globalising system, } \\
\text { in particular those constrained by the } \\
\text { emergence of major domestic pressures } \\
\text { arising from more open politics. } \\
\text { Economists had begun to question } \\
\text { the Washington Consensus's liberal } \\
\text { internationalism before the series of } \\
\text { critical junctures that began with the } \\
\text { global financial crisis of } 2008 \text { and the } \\
\text { rise of Asia. Those questions are all the } \\
\text { more relevant now, following the impact } \\
\text { of the Trump presidency in America } \\
\text { and the sudden pause experienced by } \\
\text { the global economy as a result of the } \\
\text { COVID-19 pandemic. } \\
\text { So what does the future hold for } \\
\text { emerging market democracies (EMDs) }\end{array}$ & $\begin{array}{l}\text { and what are their political, economic } \\
\text { and state-crafting options under } \\
\text { the pressures of globalisation? In } \\
\text { their article, "Democratic statecraft: } \\
\text { perspectives from an unsettled } \\
\text { global South," Lourdes Sola from the } \\
\text { University of São Paulo in Brazil, and } \\
\text { Laurence Whitehead from the University } \\
\text { of Offord in England, address these } \\
\text { problems directly. } \\
\text { These authors will present their concept } \\
\text { paper at the online congress in July } \\
2021 \text { of the International Political } \\
\text { Science Association (IPSA). Founded } \\
\text { under the auspices of UNESCO in } 1949 \text {, } \\
\text { IPSA works to support the development } \\
\text { of political science in all parts of the } \\
\text { world and to build academic networks } \\
\text { globally, linking East and West, North } \\
\text { and South. In the run-up to its biannual } \\
\text { gathering, the authors argue that it is } \\
\text { time for a thorough overhaul of the } \\
\text { assumptions behind the Washington } \\
\text { Consensus and the development of } \\
\text { emerging market economies. } \\
\text { STATE-CRAFTING } \\
\text { AND CONVERGENCE } \\
\text { This article uses the lens of "statecraft" } \\
\text { to study the comparative political } \\
\text { economies of EMDs in today's global } \\
\text { South, notably Brazil, India, Indonesia, } \\
\text { Mexico, Nigeria, South Africa, and } \\
\text { Turkey. Statecraft- the art of conducting } \\
\text { state affairs - focuses on how countries } \\
\text { manage the relationship between state, } \\
\text { market and civil society. } \\
\text { As the authors explain, for the last } \\
20 \text { years the world context has } \\
\text { been dominated by pressures for } \\
\text { globalisation, deregulation and }\end{array}$ \\
\hline
\end{tabular}

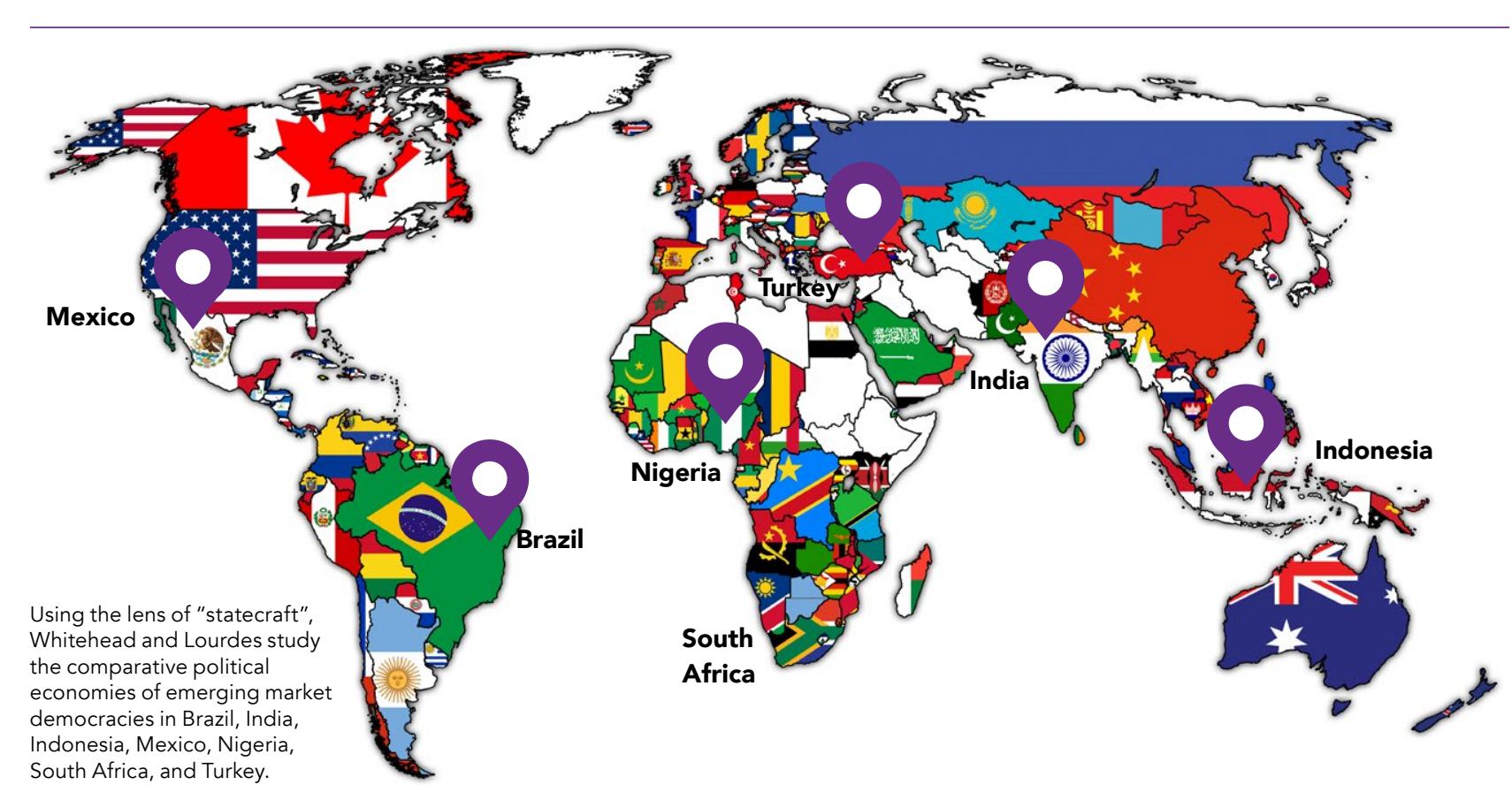

privatisation. Policy-making in EMDs has and the negotiation of positions that been directed towards "convergence" " may well seem "second best" from economic liberalisation put forward by the realities of coalition-building in the global North. The aim has been open political systems. They therefor "restructuring the relationship between argue that what is needed is "more the state and markets, while ushering in experimentation and political invention institutions embodying the principles of more political and social contestation representative democracy." and course corrections, more devising

fiscal adjustment to secure the solvency required by global investors. However, EMDs face different statecraft challenges in bringing this about.

In addition, EMDs' development paths are guided by policy-makers who in many cases derived power from an authoritarian past. The authors find

However, the article questions continued

commitment to convergence. The authors argue that comparative studies of EMDs show that convergence fails to acknowledge that

and economic liberalisation can have a different momentum and direction a different times and in different places. Countries have different legacies from the past and different challenges and trajectories for the future.

For the last 20 years the world context has been dominated by pressures for globalisation, deregulation and privatisation.

$$
\text { democratisation }
$$

means that this policymaking inheritance is not only constraining, it can create additional challenges such as internal
demands for reform demands for reform. "unitary actor", but

and second-best solutions, rather than optimal blueprints,"

\section{CHALLENGES AND RULE-MAKING}

Not only should we rethink the

convergence model to which EMDs have previously had to conform, the authors also argue that we need to look at the individual statecraft challenges EMDs face and consider EMDs as rule-

The promotion of convergence by global institutions such as the World Fund (IMF) implies that it is a "uniline transform imples that it is a "unilinear the authors find that democratic state crafting is not a given and has to be more flexible, particularly in large and new democracies and at critical junc such as the beginning of greater internationalisation. They highlight the
According to the authors, this comparative study of EMDs shows that economic reform is driven by things whilised as the need for economic stabilisation and debt reduction, and the new intern marks. All have deman has to work with domestic stakeholders and historical institutions.

According to the article: "While conditions under which the agenda of proced to conduct the transformative processes involved necessitate a special "new democratic rules in both domes The global economy also has to take account of changing power asymmetries, incluading, for example, globalisation is internalised, the powers policies and in globalising institutions." even keener to assume thave beco, 

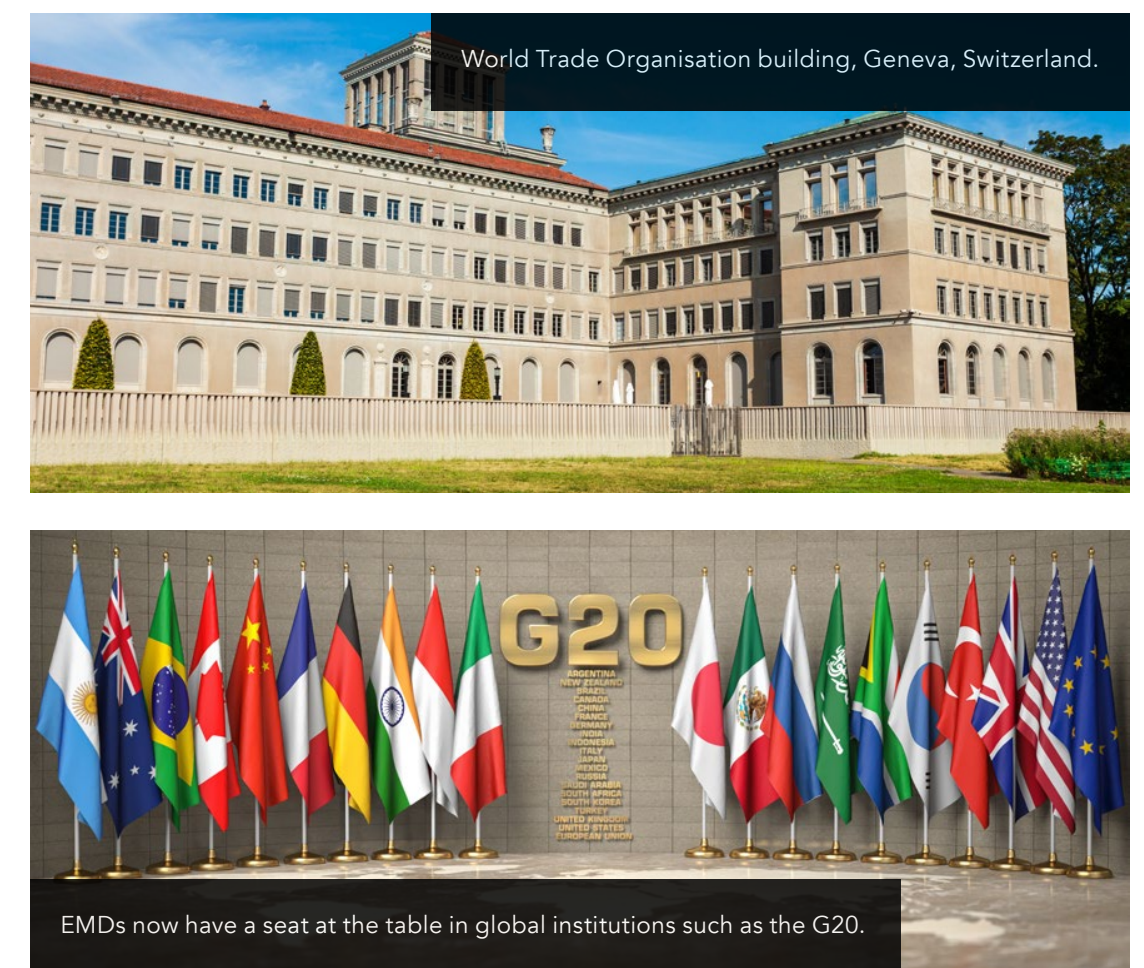

rule-makers. Too big and too complex the challenge of domestic coalitions to accept the role of rule-takers, larger formed either in support of reform EMDs now have a seat at the table in and globalisation, or in resistance to global institutions such as the World liberalisation and internationalisation Trade Organization (WTO) and the EMDs may also have to reconcile uneven G20. In addition, Brazil, Russia, India, patterns of development, which brings China, and South Africa (BRICS) have into question the role of a democratic established their own multilateral BRICS Development Bank.

\section{DEMOCRATIC FEDERALISM}

The authors find that another factor that affects the state-crafting options of larger EMDs is that their size affords$$
\text { (n) }
$$

Democratic federalism is an ongoing process and implementing politicoeconomic strategy requires significant political negotiation, coalition-building of the co-

\section{Mass international tourism, just-in-time} value chains, and foreign investment patterns could be reversed or even wiped out.

Their defining features are the centrality As the authors explain: "Crafting of the state, the commitment to state democratic federalism is thus one of the capitalism, and the importance attached instances where the logic of democracy to a state-led economy for economic and other reasons according to their development path.

However, larger EMDs tend to have federal systems of state structure, In addition, they may have to deal wh

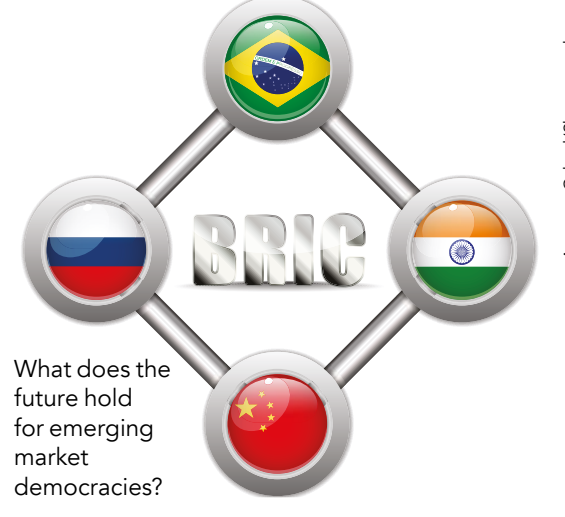

he world economy. For example, Dani Rodrick's promotion of "moderate globalisation" seeks to resolve the "trilemma between reconciling desires for deepening democracy, reinforing national sovereignty, and global participation. They also look (proposed by Albert O. Hirsclentect as far back as 1973 argued that large sections of society tolerate inequality in the hope that they will eventually also benefit financially.

The abiding principle, however, is that post-pandemic, the world will be in a vey different place, and it is exceedingly hard to map the future of the world economy in general and its impact on EMDs in particular. The authors recognise that digitalisation, the rise of the knowledge economy and decarbonisation will continue to be the main driving forces. However, other previously "relentless" trends such as mass international tourism, just-in-time value chains, and foreign even wiped out.

Whatever the outcome, the authors are confident that the major countries of the global South will remain key players - their citizens will expect them to adapt, and they will reposition themselves in diverse ways. They conclude, however, that: "It remains to be seen what kind of democracy (if any) will emerge from the present universal and transformative critical juncture, but these large, complex, and deeply-divided societies will require skilled political management, careful and sequential policy design and co-ordination, and some means of sustaining popular support and understanding. In short, statecrafting

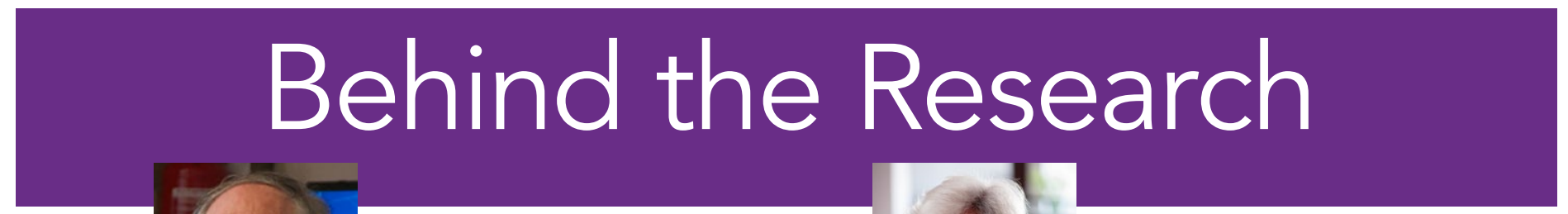

Laurence

Whitehead

E: Laurence.whitehead@nuffield.ox.ac.uk / itre: loursola@usp.br W: https://www.nuffield.ox.ac.uk/people/profiles/laurence-whitehead/

\section{Research Objectives}

The two authors challenge political scientists to rethink the democratic state-crafting options for emerging

\section{Detail}

Bio

Laurence Whitehead is a Senior Research Fellow in Nuffield College, Oxford, and the Current Chair of Research Committee 51 on International Political Economy of the International Political Science Association (IPSA).

Lourdes Sola is a Professor of Political science at the University of São Paulo. She was President of IPSA, and the founder of its Research Committee 51.

Funding Interidionar College

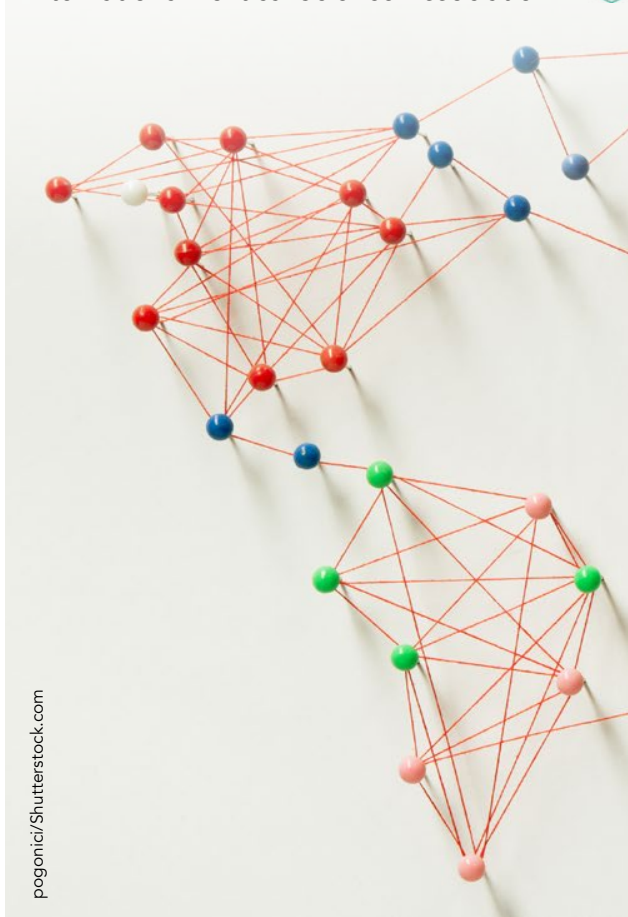

\section{References}

Sola, L. \& Whitehead, L. (2020). Democratic Statecraft: erspectives from an Unsettled Global South.

\section{Personal Response}

Do you believe the pandemic will enhance or diminish the desire for countries to make collective policy decisions?

II The pandemic generates near term public health emergencies, medium term macro-economic strains, democracies of the global South These across the are neither simple nor uniform, but overall they incease the need for effective collective policy responses while
making their delivery harder.

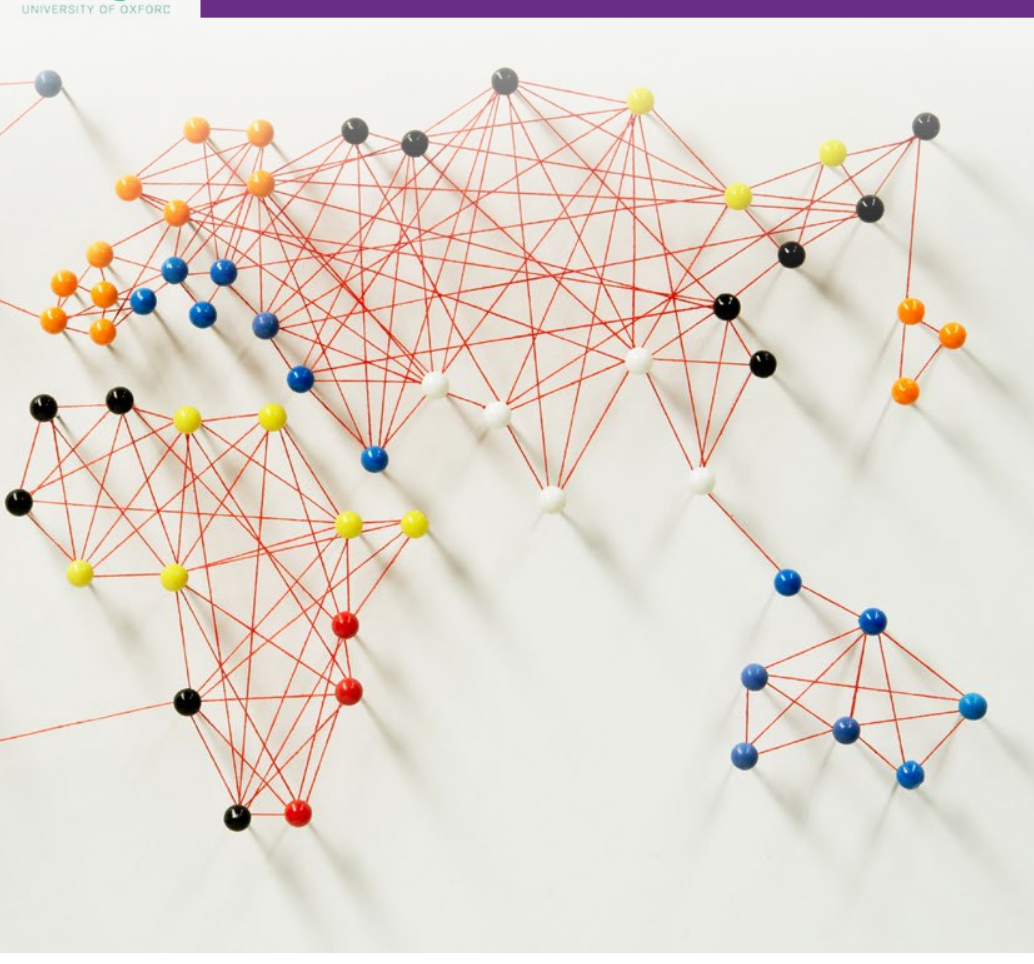

